\title{
PROFESSIONAL LIMITATIONS AND CAPABILITIES OF PEOPLE WITH VARIOUS DISABILITIES
}

The availability for work and durability of employment of disabled people depends on a range of factors. These are factors of demographic-social, cultural, economic, legal, organizational-institutional nature. These are also factors of biomedical nature (psychological-personal and medical) that shape individual functional abilities of the individual, i.a. the nature of cognitive processes, knowledge acquisition, development of skills and competences that are significant from the point of view of professional path, efficiency of work that is provided, mobility, flexibility or adaptability skills. The aim of this paper is to discuss functional nature of people with various disabilities in the context of professional limitations and capabilities.

Keywords: disability, functional issues of people with various disabilities, professional possibilities of people with various disabilities.

JEL Classification Codes: E24.

\section{Introduction}

The availability of work and durability of employment are determined by a series of factors of economic and non-economic nature. In case of disabled people the chances to begin and to provide work are shaped by a series of external factors that result from the nature of given disability. The disability negatively affects professional capabilities; on one hand, this is the case due to reduced level and/or scope of functionality, and on the other hand, a stereotypical approach to these limitations. This is the case because of the fact that the existence of problems on the biological level reduces the scope

\footnotetext{
${ }^{1}$ Ph.D. Student, K. Pulaski University of Technology and Humanities in Radom, Faculty of Economics and Legal Sciences.
} 
of human functional capabilities that shape potential professional opportunities of the individual. The collectivity of disabled people is highly varied in this matter. Although, in majority of the cases, the biomedical factors indicate only a partial loss of possibilities to provide work (Majewski, 2007a, p. 12), the vast majority of disabled people has difficulties with getting a job, which leads to socio-economic dependency (Borek, Olszewski, 2017, p. 27).

The level of their professional activity and employment has been very low for many years (see more: Borek, 2005, 2006) and regardless of the fact that they have the right to work, and broadly speaking, to have an active and independent life (Karta Praw Osób Niepelnosprawnych, 1997), they cannot be subject to discrimination, and the process of their activation is supported with public funding (Borek, 2012, pp. 125-132). One of the key factors that are responsible for these circumstances is stereotypical, generalized attitude towards the professional capabilities of the disabled people (Borek, 2017, p. 156), which explains the need to promote knowledge about functional nature and professional capabilities of people with various disabilities.

The method of a critical analysis of the literature was used in this article, on the basis of which the cause-and-effect relationships between the availability for work and disability were determined. On the basis of these findings, the application conclusions were formulated, which serves to improve the efficiency of the professional activation process of the disabled people.

\section{The factors that determine the availability for work}

The review of subject literature indicates the existence of numerous systems that "order" the above-mentioned factors.

According to Gorczycka (2005), they may be divided into three groups. The first one includes factors related directly to the person, social environment of his/her life (people important to such person) and environmental factors of institutional nature, and more general nature with respect to the other indicated factors. In case of individual dimension, a significant impact is made by psychophysical features of a human (level of disability, personality and attitude towards self), socio-demographic features (approach to own disability that is shaped by the family, education, profession, skills, qualifications and other factors that determine the social status of an individual).

In the field of social environment of life, the key role is attributed to the role of work in a value system that is followed by closest family members, a function fulfilled by the disabled person in the family and attitude of the closest people to his/her professional activity and support of the environment (family, peers, neighbors, work, organizations and associations) within the scope of taking up and performing work. The category of the so called general-institutional factors relates to the influence of demographic and 
economic conditions, including the situation on the job market. This also applies to functionality of physical environment of life and place of residence of the disabled person, knowledge and social attitudes towards disabled people and their rights, including the right to work, provisions of law, pension-retirement system. This also applies to the influence of government and non-government organizations, mass media and broadlyunderstood cultural conditions (Gorczycka, 2005, pp. 46-54).

Slightly different classification of determinants was proposed by Safilios-Rothschild (1976) who stated that the capabilities to take up and perform work are determined by 5 groups of factors, i.a.: professional variables, socio-demographic, psychosocial, personal and medical conditions (Safilios-Rothschild, 1976, p. 89). The professional variables include the influence of individual qualifications, need-demand relationships that apply on the market, professional work hierarchy and membership in trade unions. The socio-demographic conditions indicate the importance of the influence of age, sex, education and family-material situation of the person. The psycho-social factors also include the influence of attitudes represented by social work environments with respect to disable people and their rights, self-evaluation of the disabled person with respect to his/her level of independence from the surrounding, his/her professional aspirations and aspects of private life (i.a. ways to spend free time, sex life, etc.). The medical conditions are related to the influence of the causes (type) and level of disability and its duration (the moment of occurrence), and also the subsequent professional complications that result from damage to the organism (psycho-physical and psychiatric) and that determine the ability to function and a subjective evaluation of own health conditions and chances for its improvement. The personal factors include the level of intelligence, adaptability skills of the individual, the ability of emotional self-control, and self-criticism and motivation to work.

According to Kryńska and Poliwczak, the factors that determine professional activity of the disabled people include socio-demographic (education, sex, age, occurrence of disability, family and material situation), psycho-social (evaluation of own level of independence) and personal factors (intelligence, motivation, adaptability skills, ability of emotional self-control and self-criticism) (Kryński, Poliwczak, 2013, p. 9).

The classifications that are indicated herein order the factors that shape the professional opportunities of each individual, including the disabled people. Thus, the unfavorable professional position of the disabled people is the aftermath of relatively lower functional ability that determines the possibility to educate, develop or work efficiency. The knowledge of functional nature of people with various disabilities makes us aware that many of them may work and do it relatively efficiently on condition that the work entrusted to them and the location for its provision consider individual functional limitations. 


\section{Nature of functioning of people with various types of disabilities}

The subject literature proves the existence of numerous definitions of disability. They may be considered according to the following categories:

- general definitions that represent generalized approach to disability;

- definitions for particular purposes that are developed on the basis of particular criteria for the purpose of particular disciplines; and

- definitions of particular categories of disabled people (that reflect internal differentiation of collectivity and functional nature of particular groups) (Majewski, 1994, p. 139), structures of hierarchy that were developed, among others, in provisions that regulate the issues of granting the certificate of disability and its level.

In view of the provisions that are indicated, the collectivity of disabled people was divided into 12 groups (Rozporządzenie Ministra, Gospodarki, Pracy i Polityki społecznej w sprawie orzekania o niepełnosprawności i stopniu niepełnosprawności, 2003), each of which was assigned a particular numerical-literal symbol recorded on the certificate that is an integral element of application document of the disables person that seeks employment. The analysis of functional nature of particular disabilities indicates that the collectivity of the disabled people is highly varied with respect to bio-medical features that are important in terms of professional work (Boryczka, 2006, p. 27). This fact makes it impossible to develop a strict catalogue of recommendations and contraindications for employment of people with particular types of disabilities (Kowalczyk, 2003, p. 50, Majewski, Szczpankowska, 1998, p. 23) and justifies the need for individual approach in this matter.

People with intellectual disability (01-U). This disability is shaped during the developmental period and its substance consists of complex interactions that occur between the delay of maturation, development and regress (Kirenko, 2004, pp. 172-173). It is of global nature. The disorders are related to adolescence, development of personality, social maturity, psychomotor development, speech, orientation-cognitive processes, learning rate, acquisition of skills and effect durability (Majewski, 2007a, p. 68; Mrugalska, 1996, pp. 117-138). From the professional point of view, these difficulties are related to work that requires skills within the scope of objective evaluation of reality, concentration, analysis and drawing conclusions, interpretation of phenomena, communication, decision making and problem solving (Gesternkornowa, 2007, pp. 17-20; Majewski, 2007a, p. 69). The source may also be the hyperactivity or even aggression or phlegmatism (Gesternkornowa, 2007, p. 72) and co-existing disabilities that frequently accompany the individual (such as: disability related to the sight, hearing, movement, autism, epilepsy, etc.) (Mrugalska, 1996, pp. 117-138). The common pejorative attitude towards their professional capabilities (Kirenko, 2006, p. 49) condemns majority of these people to economic and social dependency (Barczyński, 2006, p. 23). The professional activation of this group requires overcoming numerous barriers in employment (barriers from 
the side of employers, parents). The employers often believe that people with mental disability cannot be good employees since there are unpredictable, irresponsible, dependent and are not able to learn due to their resentment towards change and lowered intellectual capability.

The employers are also worried about additional duties, costs and potential bias by other employees. Lack of knowledge about professional capabilities and nature of intellectually disabled people among the employees, constitutes an obstacle in employment. The attitudes of the parents also contribute to limited professional activity of people with intellectual disability, since they do not believe that their children may be good employees. They see the work environment as a threat to their children. The parents are often overprotective and do not accept higher independence or autonomy of the adult child (Malik, 2011, p. 70). The views in this matter are overturned by achievements of science, in view of which the indicated disability is of dynamic nature. This means that the vast majority of people that suffer from it, who are covered by thorough rehabilitation that is started early, is able to reach a level of social maturity and professional abilities that make it possible to work; whereas the level of its difficulty should take functional limitations into consideration. However, it is not recommended to entrust these people with complicated work that requires development and independence, where the process of decision making exceeds the $60 \%$ of the working time (Łuczak, Kurkus-Rozowska, Kamińska, 2007, p. 22; Mrugalska 1998, pp. 130-138; Tokarski et al., 2007, p. 9). High employment opportunities for people of the above-mentioned group are created i.a. in gardening, laundry rooms, cleaning works, care services, trade/warehouses (packing and delivering goods to the customers), element cutting and assembly (Tokarski et al., 2007, pp. 69,73), agriculture, public service, gastronomy, leisure and hotels, recycling (Barczyński, 2006) work as locksmith-carpenter, tailor, bricklayer, mechanic (Majewski, Miżejewski, Sobczak, 2007, pp. 62-67) etc.

Mental illnesses (02-P). People with mental disability, from the point of view of functional limitations and professional capabilities, are a highly varied groups. The mental disability may result from endogenous diseases (schizophrenia, affective disorders, congenital defects of the central nervous system of metabolic origin), causal factors of exogenous origin (e.g. reactive depression after loss of someone close) and organic brain damage (as a result of skull trauma, inflammation of the central nervous system, poisoning, addiction to alcohol, drugs, etc.) (Majewski, Miżejewski, Sobczak, 2007, pp. 67-69; Meder, 1998, pp. 145-162). The main functional issues related to the disorders of the mental sphere, emotional sphere and activity (hyperactivity, apathy), personality, consciousness and intellectual disorders (Majewski, Miżejewski, Sobczak, 2007, pp. 67-69) and deficiencies within the scope of social skills (Oleś, 1998, p. 10). Relatively frequent periods of normal functioning and periods of severity of symptoms accompanied by improper behaviors, occur interchangeably. In many cases, with treatment conditions maintained, the remission occurs rarely. The issues related to professional 
activation, besides functional nature, are caused by side effects of therapies that are applied (e.g. mild dementia, slowness, etc.), highly limited predictability within the scope of remissions and stereotypical attitude towards the disease. People with mental disorders are often subject to the process of self-exclusion due to concerns related to judgment by society, which does not favor their professional activation. Very often, they are not able to talk about it and are afraid of it, as they are afraid of the social reaction to their professional activation (Duda, Kukla, Zając, 2014, p. 103).

Considering the role of functional aspects that are being disordered by the illness in the process of human professional activation, people with intellectual disability are one of the most disadvantages groups of the job market (see more: Borek J., Borek E., 2015; Borek, Krysik, Brosz, Chludziński, 2008) which is proven by i.a. relatively higher value of support that compensates the higher costs of their employment) (Borek, 2008, p. 72). The most serious issues are related to people with significant deficiencies of the emotional sphere (Kołodziej, 2005, pp. 93-94; Kołodziej, 2006, p. 148) and the alternative to the employment is supported employment. Current experience indicates, however, that people that belong to this group may be activated, and work positively affects their social and biomedical functioning. Work on the open market conditions is recommended mainly for people in case of whom the severe symptoms resolved for the benefit of relatively long periods of relative good health (Majewski, 2007a, pp. 78-79). The contraindication for people with mental illness is work under constant stress, work at nights, or at heights. However, it is recommended to employ them for work that requires movement that stimulates their interests, sense of achievement and responsibility (Hulek, 1969). Significant opportunities are created in i.a. agriculture, gardening and handcraft (leather accessories, tailoring, assembly works, etc.), gastronomy and hotel industry, laundry services (Majewski, Miżejewski, Sobczak, 2007, p. 69-73) and animal breeding (Barczyński, 2006)

Voice, speech, and hearing disorders (03-L). This group includes people with slight damage (20-40 db) and medium damage (40-70 db) and significant damage (70$90 \mathrm{~dB}$ ) and profound damage (over $90 \mathrm{~dB}$ ) the two latter are deaf and deaf without speech (Szczepankowski, 1998, pp. 67-70). The substance of the disability is inability to hear, problems with audio communication (on various levels), and sometimes damage to the tympanum, and also problems with body balance. It is indicated that hearing disability is a significant social problem. A significant role in the communication process is lip reading (Kuc-Woyciechowska, 2007, p. 11). The people that belong to this group do not have any major difficulties with performing their professional duties, and the exception are people with balance disorder. The source of their struggles is a limited and/or lack of availability of acoustic signals from co-workers and from the work environment (Majewski, 2007d, p. 29) that affect orientation, safety and efficiency. It may also apply to limitation of intellectual abilities and unprepared social work environment (Majewski, Miżejewski, Sobczak, 2007, pp. 62-67) or lack of actions that aim at developing the 
skills of communicating with the surrounding environment (Coutler, 1974). According to Walkowska, a certain obstacle may also be issues with understanding particular words. The dictionary of the deaf people does not include some words as they are replaced with simpler ones that are not always accurate. The more specialized words, the more problems there are with communication (Walkowska, 2008, p. 158). Works that are contraindication are works that require very good hearing, clear verbal communication and that are threat to the remaining senses where there are many acoustic signals, works at heights, with machines and devices in motion (Łuczak, Kurkus-Łozowska, Kamińska, 2007, p. 22; Szczepankowski, 1998, p. 78-80). In case of this group, there are no other contraindications related to their employment. It is also important that the work that they are entrusted with considers individual deficits and potential, including intellectual potential (these people are also able to work under stress) and adaptation techniques (based on e.g. replacing the acoustic signals with visual ones, including written communication, body language, etc.) (Tokarski et al., 2007, p. 10)

Eye diseases (04-0). This group includes people who are completely blind (or who have the sense of light) and people with minimum vision that include people with damage to central vision, high short-sightedness, damage to the peripheral vision and people with greatly reduced vision with stereoscope (binocular) vision disorders. These limitations and capabilities correspond with the scope and nature of the indicated disability, the level of dysfunction stability (Majewski, 2004, pp. 15-22) and the moment of its occurrence (Majewski 2007b, p. 33). The substance of limitations, from the professional point of view, are difficulties related to receiving visual stimuli that result in i.a. lowered motor ability (manipulative and locomotive activities) and difficulties within the scope of decision making (Majewski, Miżejewski, Sobczak, 2007, p. 56). The contraindications are related to work that requires much physical effort, good vision, good assessment of distance, frequent moving within the area and performing activities at heights with the use of hazardous machines and devices under electric voltage (Tokarski et al. 2007, p. 10), driving vehicles and other transporting devices (Hampel, Gadzinowska, 2017, p. 100).

Despite many years of professional discrimination of members of this collectivity, especially in case of the open market (Majewski, 1995, p. 111), they may perform professional work (Kotowski, 1998, p. 59). An important role is fulfilled by compensational role of hearing (Kowalik, 2006, pp. 34-36) and touch (Teczka informacyjna. Sprawni niepełnosprawni, 2005, p. 10). The necessary adjustments are related to i.a. proper lighting, application of particular colors (Majewski, 2004, p. 15). Special opportunities for employment of these people are created by intellectual work, especially with the use of computers (Bogusiewicz, Boczkowska, 2006, p. 42), as well as services, minor production and manual work (Majewski, 2007b, p. 33). People with blindness and highly reduced vision work in positions where sight and non-verbal stimuli are not so important in performing their work (Suchińska, 2008). 
Musculoskeletal dysfunctions (05-R, motor). This group includes people with limited ability of upper limbs, lower limbs and spine (i.a. diseases, damages and deformations of the skeletal, muscular, nervous system (Moskalewicz, 1998, p. 105), palsy and paresis - monoplegia, hemiplegia, paraplegia and tetraplegia) (Majewski, 2005b). From the professional point of view, a classification was acquired that divides the members of this group into people with: upper limb dysfunction due to damage to the spinal cord, lower limb dysfunction that does not result from damage to the spinal cord, joint dysfunctions (hip joint dislocation, stiff hip joint, arthritis, ankylosing spondylitis and club foot) and dysfunctions of motor organs of cerebral origin or damages to the spinal cord (infantile cerebral palsy, increased muscle tone, or consensual movements symptoms, damage to the cervical, thoracic, or lumbar part of the spinal cord) (Migas, 2007, p. 16). The substance of these limitations is related to i.a. motor ability, moving around within the space, learning rate and capacity of memory (Górska, 2007, p. 25). The contraindications include demanding physical work that requires walking or standing (lower limb dysfunctions) or that requires full manual ability (upper limb dysfunctions) or a forced position (Górska, 2007, p. 25; Tokarski et al., 2007, p. 10). A significant role is fulfilled by compensation mechanisms such as functions of upper limbs that are partially intercepted by lower limbs. Similarly to other disabilities, individualized approach to the issue of adequacy of the entrusted work and location for its performance is required with respect to the functional capacities of the candidate.This applies i.a. to adjustment of position, and the level of complexity to the intellectual capacities, adjustment of the necessity to move to the abilities or the adjustment of the nature of activities to manual capabilities (Górska, 2007, pp. 25-28; Majewski 2005a, pp. 16-17, 2007c, pp. 9-10). This also applies to the equipment of the work station (Kirenko, 1998, pp. 93-99; Moskalewicz, 1998, pp. 108-116), organization of means of transportation to work, adjustment of the building. High work opportunities e.g. in case of people with lower limb disability are created by office work, especially by the computer.

Epilepsy (06-E). The substance of the disability are repeated non-convulsive seizures (the so called auras with clouding of consciousness) and short seizures (short loss of consciousness, objects slipping through a persons' hand). The seizures may also be complex (the so called temporal, the feature of which are clouding of consciousness and automatic performance of complex activities such as sticking out the tongue, swallowing, rubbing hands, smacking, correcting clothing, etc.). The symptoms may be of motor, sensual, vegetative and emotional nature and lead to a major seizure) and result in major seizure that is accompanied by convulsions, loss of consciousness and balance, jaw spasms, biting the tongue or memory loss. Also, the changes in personality (characteropathy) may occur. Epilepsy may be a basic unit or may accompany other diseases of mental or neurological origin (Jakubowska, Kuran, 1998, pp. 168-169). Epilepsy limits human capabilities on various levels. Some patients present no visible features 
of disability but sometimes the disease prevents independent existence. Thus, the work opportunities for these people vary significantly (Noskowicz-Bieroniowa, 2000, p. 129).

The nature of symptoms determine professional capabilities of the individual. People with significant disorders are usually incapable of working, and in case of more profound lesions, the supported employment is preferred. The remaining groups of people may work on the open job market in properly adjusted conditions. The contraindications related to the employment include work that imply significant physical effort, at heights, near fire or water reservoirs, with machines in motion, with live machines as well as independent work and work performed at night (Jakubowska, Kuran, 1998, pp. 168-169; Tokarski et al., 2007, p. 10). People who suffer from epileptic seizures should also avoid working underground and under water (Hopkins, Appleton, 1999, p. 128). The opportunities for employment are created also in gardening and wide range of services that do not require live operating machines or devices in motion or work performed at heights.

Respiratory and cardiovascular diseases (07-S). This group includes people who are disabled due to cardiovascular (blood vessels and heart) and respiratory (i.a. chronic asthmatic bronchitis, silicosis, allergic bronchial asthma, tuberculosis, chronic obstructive lung disease (COLD) emphysema, asthma) (Borak-Kwapisz, 1998, p. 183-189). These diseases, similarly to cancers, are considered one of the most significant health hazards in the well-developed and developing countries (Stan zdrowia ludności, 2004). The substance of limitations due to cardiovascular issues are related to cardiac muscle contractility, pain, anxiety, depression, hypochondria or hysteria. In case of people with respiratory disability, the issues are related to proper oxygen intake and its delivery to cells, which may lead to lesions that result from oxygen deficiency; there is also an excessive exhaustion and sweatiness, weakness, anxiety. Both categories constitute a contraindication for work connected with significant psycho-physical pressure and unfavorable work rhythm, significant mobility and unfavorable temperature. In case of people who are disabled due to respiratory system disorders, the contraindications include work in unfavorable microclimate conditions (presence of substance that irritate the respiratory tract in the form of fumes, dusts, excessive humidity, etc.) (Tylka, 1998, pp. 183-201).

Digestive system diseases (08-T). This group includes people who are disabled due to chronic diseases of intestines, esophagus that lead to long-term disorders, stomach resection complications, maldigestion syndrome, chronic pancreas diseases and GI cancers. The functional nature of people with disability that result from digestive system diseases is connected mainly to pain, improper digestion, digestion and defecation disorders, weakness and nerve tensioning. The contraindications for employment include only work in conditions that make it impossible to take medication and eat meals on a regular basis (Łuczak, Kurkus-Rozowska, Kamińska, 2007, p. 23), and in justified cases, performing hard work, work under pressure or work at varying temperature (Hampel, Gadzinowska, 2017, p. 101) 
Urogenital system diseases (09-M). This group includes polycystic kidney disease, urinary tract disorders that lead to kidney failure, uremia, and malignant cancers of urogenital system. The contraindications include work in conditions of varying humidity and air temperature, low temperature with a fixed schedule and breaks and in conditions that lead to severity of symptoms (Łuczak, Kurkus-Rozowska, Kamińska, 2007, p. 23; Polak-Sopińska, 2008, p. 210).

Neurological diseases (10-N). This group includes people, the disability of whom results from diseases of the nervous system, namely the peripheral nerves, spinal cord and brain. This includes i.a. multiple sclerosis (SM or SD), the consequence of which is chronic exhaustion by cognitive activity, deterioration of visual acuity, paresis and motor, sensual, sphincter, speech, balance and motor coordination disorders (Johnson, Amtmann, Yorkston, Klasner, Kuehn, 2004). The selectin of work should consider the type and severity of symptoms and potential necessity for their further adjustment due to the fact that the disease is usually of progressive nature. High employment opportunities include intellectual work (Kuran, 1986). The group in question includes people who are disabled due to brain strokes, in case of whom the determinant of ability is symptom dynamics (Tokarski et al., 2007, p. 11). It is stated that these people should not perform any work at heights, work that requires physical effort or forced position, near hazardous machines in motion or work that implies exposure to neurotoxic substances (Jakubowska, Kuran, 1998, pp. 165-180; Łuczak, Kurkus-Rozowska, Kamińska, 2007, p. 23).

Other (11-I), including endocrinologic, metabolic and enzymatic diseases, communicable diseases of animal origin, defacement, hematologic diseases. The variety of contraindications and professional capabilities of members of this group depends strictly on the nature of particular diseases (Łuczak, Kurkus-Rozowska, Kamińska, 2007, p. 23) and the criterion of their evaluation may be a dysfunctional organ or forms of treatment. Usually, the contraindication is the so called hard work.

Holistic developmental disorders (12-C). The main unit of this category is autism that usually presents itself during first three years of life in the form of neurological disorder that affects the brain functions (DSM-IV-TR) (APA - American Psychiatric Association. Diagnostic..., 2000). It is often considered a mental disease due to life-long difficulties within the scope of cognitive, emotional and social functions (Szczupał, 2007, p. 228). It is accompanied by problems with communication, interpretation of non-verbal messages that is adequate with respect to the content and messages that contain messages of abstract nature and understanding of new terms (Matson, Benavidez, Compton, Paclawskyj, Baglio, 1996, pp. 433-465). Also, the disorder affects the abilities within the scope of control of behavior and principles of social life (Goodman, Scott, 2000, p. 64), processes of understanding behaviors and human emotions and interpretation of signals from the surrounding environment, which often leads to presentation of emotions that is inadequate to the situation (anger, aggression, auto-aggression, lack of obedience 
(Danielewicz, 2005, pp. 31-42; Mesibow,Handlan, 1997, pp. 309-322). The people who suffer from autism are often withdrawn, they isolate, convey their thoughts in nonprecise manner, tend to lose their own "self" and are emotionally labile (Willims, 2005), which increases the risk of social isolation (Horner, Carr, Strain, Todd, Reed, 2002, pp. 423-445). Due to complex consequences of autism, people who suffer from this disease are very difficult to activate professionally. The estimated data shows that only $1 \%$ of autistic people actually works. Regardless, people who suffer from autism must be prepared proportionally to their ability to live independently, including work.

\section{Summary and conclusions}

From the point of view of possibilities to take up and perform work, the special group are people, the disability of whom results from two or more causes - the so called complex disabilities. This group includes i.a. deaf people, people with intellectual disability and damaged motor organ, people with intellectual disability with epilepsy, blind people with intellectual disability and epilepsy, people with cardiovascular system failure and diabetes.

The simultaneous damage to at least two organs or systems leads to a series of consequences that limit functional capabilities of a person in almost all walks of life. Thus, in many cases people who suffer from complex disability do not qualify for any work. They may, however, take part in therapies that are carried out through occupational therapy. However, it is not a general rule, since the capabilities and limitations regarding employment must be determined individually on the basis of a type and level of co-existing disabilities (Tokarski et al., 2007, p. 11). Similarly to people with other types of disabilities, there is a need to select activities and professional tasks that are adjusted to individual capabilities of a person and there is a need to adopt the station or a workplace (Majewski, Miżejewski, Sobczak, 2007, pp. 74-75). The evaluation of functional problems and determination of professional capabilities of people included in the same group also requires individualized approach since in particular cases, the disability may only hinder, and in other cases limit, and in yet other cases make it impossible for particular person to perform work.

\section{Conclusions}

The analysis that is presented in this paper makes it possible to draw the following conclusions:

1) the review of determinants of professional activity indicates that the availability of the person for work and durability of such employment is determined by a series of factors. These include factors of socio-demographic, cultural, economic, legal institutional-organizational nature and also the especially important, from the 
point of view of professional capabilities of person who suffer from disabilities, factors of biomedical nature (psychological, personal and medical);

2) the biomedical conditions determine possibilities for development of the individual within the scope of knowledge acquisition, development of skills and competences that are significant in terms of professional development and efficiency of work that is provided by such individual, professional mobility, flexibility and a level of adaptability skills;

3) the analysis of functional nature of people who suffer from disability proves that they are a collectivity that is highly varied according;

4) the factors that are significant in terms of influence of biomedical conditions on the scope and level of limitations and potential opportunities to provide work by people who suffer from disability, include: cause and level of disability, moment of its occurrence and severity of symptoms;

5) the review of functional capabilities of people who suffer from various disabilities proves that majority of them is able to find job and perform work that takes professional limitation into consideration. Failure to consider them in the process of professional activation negatively affects the efficiency of work and constitutes a threat to employment durability and availability of positions for people who suffer from disabilities;

6) the evaluation of potential possibilities of employment of a person with disability should be of individual nature that considers limitations and professional capabilities, requirements of the workplace, position and scope of activates and chances to alleviate the existing limitations (as determined through available tools that support professional activation of people who suffer from disabilities);

Regardless of the fact that the evaluation of the ability to work on a given position is carried out by occupational medicine physician, the decision regarding potential employment is to be made by the employer. This fact justifies the need for common education of the employers within the scope of professional capabilities of people with various disabilities and tools that make it possible to alleviate the barriers that hinder the process of their activation.

\section{References}

APA - American Psychiatric Association. Diagnostic and Statistical Manual of Mental Disorders, (2000) [DSM-IV-TR] (Fourth Edition, Text Revision), Washington DC.

Barczyński A. (2006). Rynek pracy a potrzeby i oczekiwania osób z niepełnosprawnością intelektualna. „Aktywizacja Zawodowa Osób Niepełnosprawnych”, nr 3-4.

Bogusiewicz K., Boczkowska K. (2006), Komputer narzędziem aktywizacji zawodowej osób z dysfunkcją narządu wzroku, „Aktywizacja Zawodowa Osób Niepełnosprawnych”, nr 3-4. 
Borak-Kwapisz J. (1998), Osoby z chorobami układu oddechowego, [w:] Ostrowska A., Szczepankowska B. (red.), Problem niepełnosprawności w poradnictwie zawodowym, Zeszyty Informacyjno-Metodyczne Doradcy Zawodowego, Krajowy Urząd Pracy.

Borek J. (2006). Aktywna polityka rynku pracy szansą na aktywizację zawodową osób niepełnosprawnych, „Aktywizacja Zawodowa Osób Niepełnosprawnych”, nr 3-4 (7-8).

Borek J. (2005), Niepełnosprawni woj. mazowieckiego wg Narodowego Spisu Powszechnego, [w:] Staręga-Piasek J. (red.) Niepełnosprawność i Rehabilitacja, nr 4, IRSS, Warszawa.

Borek J.(in cooperation with Krysik K.) (2008). Część I, Podsumowanie i wnioski, [w:] Borek J., Krysik K., Brosz K., Chludziński K., Wchodzenie, utrzymanie, powrót na rynek pracy osób po chorobie psychicznej. Raport z ewaluacji projektu, PFRON, Agencja Nasze Sprawy, Katowice.

Borek J. (2012). Wspieranie zatrudnienia osób niepełnosprawnych a zmieniające się warunki otoczenia. In Gagacka M., Gołebiowski M. (red.) Wsparcie społeczne. Między teorią a praktyka. Wybrane problemy, UTH im. K. Pułaskiego w Radomiu, Radom.

Borek J. (2017). Praca osób niepełnosprawnych-litera Konwencji ONZ a polska rzeczywistość. In Garbat M., Paszkowicz M. (red.) Osoby z niepełnosprawnościami w polityce społecznej. Tom 2: 25-lecie systemu rehabilitacji zawodowej i społecznej w Polsce, UZ, Zielona Góra.

Borek J., Krysik K., K.Brosz., K.Chludziński (2008). Wchodzenie, utrzymanie, powrót na rynek pracy osób po chorobie psychicznej. Raport z ewaluacji projektu, Nasze Sprawy, PFRON, Warszawa.

Borek J., Olszewski M. (2017). Ekonomiczne i społeczne przesłąnki aktywizacji zawodowej osób z niepełnosprawnościami, [w:] Klementowska A., Pietrulewicz B. (red.) Edukacja i praca w procesie rozwoju zawodowego, PTF, IIBiNoP, UZ, Zielona Góra.

Borek J., Borek E. (2015). Aktualne problemy aktywizacji zawodowej osób z niepełnosprawnością psychiczna, [w:], Paszkowicz A., Garbat M. (red.) Osoby z niepełno sprawnościami na współczesnym rynku pracy. Ku pełnemu uczestnictwu w rynku pracy, UZ, Zielona Góra.

Boryczka M. (2006). Osoby niepełnosprawne w środowisku lokalnym, „Aktywizacja Zawodowa Osób Niepełnosprawnych", nr 1-2 (5-6).

Coutler S. J. (1974). The totalny deaf, the Deafned, the Hard-of-Hearing Signer, „Educational and Psychological Aspects of Deafness Springfield".

Danielewicz D. (2005). Zachowania agresywne, samouszkadzające i stereotypowe młodzieży i młodych dorosłych z autyzmem - przegląd badań, [w:] Szczupał B. (red.), Młodzież niepełnosprawna - szanse i zagrożenia w aktualnej rzeczywistości społecznej, Kraków.

Duda W., Kukla D. Zając M. (2014). Elementy zarządzania karierą zawodową osób z niepełnosprawnością, AJD, Częstochowa.

Gersternkornowa Z. (2007, second quarter), Zespół Downa - problem genetyczny i społeczny, „Marzenia i Fakty”, Kwartalnik Łódzkiego Sejmiku Osób Niepełnosprawnych.

Goodman R., Scott S. (2000), Psychiatria dzieci i młodzieży, Wrocław. 
Gorczycka E. (2005). Psychologiczne i społeczne uwarunkowania aktywizacji zawodowej osób niepełnosprawnych. „Aktywizacja Zawodowa Osób Niepełnosprawnych”, nr 1(1).

Górska E. (2007). Projektowanie stanowisk dla osób niepełnosprawnych ruchowo, „Praca i Rehabilitacja Niepetnosprawnych", nr 11-12.

Hampel K., Gadzinowska Ż. (2017). Zarządzanie ryzykiem na stanowisku pracy zajmowanym przez osobę z orzeczoną niepełnosprawnością, [w:] Paulina Ucieklak-Jeż (red.) PRAGMATA TES OIKONOMIAS, Praca Naukowa Akademii im. Jana Długosza w Częstochowie, $\mathrm{nr}$ XI.

Horner R.H., Carr E.G., Strain P. S., Todd A.W., Reed H.K. (2002), Problem behavior interventions for young children with autism: A research synthesis, „Journal of Autism and Developmental Disorders".

Hopkins A., Appleton R. (1999). Padaczka. Pruszyński i S-ka, Warszawa.

Hulek A. (1969). Teoria i praktyka rehabilitacji inwalidów. Wydawnictwo PZWL, Warszawa.

Jakubowska T., Kuran. W. (1998). Osoby z zaburzeniami neurologicznymi, [w:] Ostrowska A., Szczepankowska B. (red.), Problem niepełnosprawności w poradnictwie zawodowym, Zeszyty Informacyjno-Metodyczne Doradcy Zawodowego, Krajowy Urząd Pracy, nr 10.

Johnson K.L., Amtmann D., Yorkston K.M., Klasner E.R., Kuehn C.M. (2004, Jan-March), Medical, psychological, social, and programmatic barriers to emplyment for people with multiple sclerosis, "Journal of Rehabilitation".

Karta Praw Osób Niepełnosprawnych (Dz.U. z 1997, nr 50, poz. 475).

Kirenko J. (1998). [w:] Ostrowska A., Szczepankowska B. (red.), Problem niepełnosprawności w poradnictwie zawodowym, Zeszyty Informacyjno-Metodyczne Doradcy Zawodowego, Krajowy Urząd Pracy.

Kirenko J. (2004). Psychofizyczne i społeczne możliwości funkcjonowania osób z upośledzeniem umysłowym, [w:] Rehabilitacja osób niepełnosprawnych jako służba społeczna, Warszawa.

Kirenko J. (2006). Oblicza niepełnosprawności. Wyższa Szkoła Społeczno-Przyrodnicza w Lublinie.

Kołodziej W. (2005). Problemy rehabilitacji zawodowej i zatrudniania osób niepełnosprawnych z zaburzeniami psychicznymi, „Aktywizacja Zawodowa Osób Niepełnosprawnych”, nr 3.

Kołodziej W. (2006). Przyczyny bierności zawodowej osób z zaburzeniami psychicznymi, „Aktywizacja Zawodowa Osób Niepełnosprawnych", nr 1-2.

Kotowski S. (1998). Osoby niewidome $i$ słabowidzące, [w:] Ostrowska A., Szczepankowska B. (red.), Problem niepełnosprawności w poradnictwie zawodowy, Zeszyty Informacyjno-Metodyczne Doradcy Zawodowego, nr 10.

Kowalczyk O. (2003). Rola pomocy osobistej w procesie integracji społecznej osób niepełnosprawnych w Polsce i innych krajach, Wydawnictwo Akademii Ekonomicznej im. Oscara Langego we Wroclawiu, Wrockaw.

Kowalik R. (2006). Rola słuchu w życiu człowieka niewidomego, „Praca i Rehabilitacja Niepełnosprawnych", nr 5(97). 
Kryńska E., Poliwczak I. (2013). Warunki dotychczasowych badań dotyczących aktywności zawodowej osób niepełnosprawnych. Zatrudnienie osób niepełnosprawnych - perspektywy wzrostu. Raport syntetyczny, IPiSS, CBOS, PFRON, Warszawa.

Kuc-Woyciechowska D. (2007). Świat głuchnie, „Praca i Zdrowie. Polskie Forum Ochrony Pracy", $\mathrm{nr} 5$.

Kuran W. (1986). Padaczka, [w:] Encyklopedyczny słownik rehabilitacji, PZWL, Warszawa.

Łuczak A., Kurkus-Rozowska B., Kamińska J. (2007). Poradnik dla asystenta zawodowego spółdzielni socjalnej, Warszawa.

Majewski T. (1994). W sprawie definicji osoby niepełnosprawnej. Problemy Rehabilitacji Społecznej i Zawodowej nr 1.

Majewski T. (1995). Polityka i ustawodawstwo mające wpływ na zatrudnienie osób z uszkodzonym wzrokiem. Belfast, 22-24 czerwca 1995 r., „Problemy Rehabilitacji Społecznej i Zawodowej", nr 3.

Majewski T., Szczepankowska B. (1998). Rehabilitacja zawodowa osób niepełnosprawnych, [w:] Szczepankowska B., Ostrowska A. (red.), Problem niepełnosprawności w poradnictwie zawodowym. Zeszyty Informacyjno-Metodyczne Doradcy Zawodowego, Warszawa.

Majewski T. (2004). Rehabilitacja zawodowa i zatrudnienie osób niewidomych i słabo widzących, Warszawa.

Majewski T. (2005a). Jak zatrudnić osoby z uszkodzeniem kończyn górnych? „Praca i Rehabilitacja Niepełnosprawnych", nr 5.

Majewski T. (2005b), Rehabilitacja zawodowa osób niepełnosprawnych, CB-RRON. Warszawa.

Majewski T. (2007a). Jak zatrudniać osoby niepełnosprawne? Poradnik dla pracodawców. KIG-R, Warszawa.

Majewski T. (2007b), Jak zatrudniać osoby niewidome? „Praca i Rehabilitacja Niepełnosprawnych", nr 7-8.

Majewski T. (2007c), Jak zatrudniać osoby z uszkodzeniem kończyn dolnych? „Praca i Rehabilitacja Niepełnosprawnych", nr 6

Majewski T. (2007d). Problemy w komunikowaniu się z niektórymi pracownikami niepełnosprawnymi, „Praca i Rehabilitacja Niepełnosprawnych”, nr 11-12.

Majewski T., Miżejewski C., Sobczak W. (2007), Gmina a niepełnosprawność. Podręcznik dla samorządów gminnych z zakresu aktywizacji zawodowej i rehabilitacji społecznej osób niepełnosprawnych, Krajowa Izba Gospodarczo Rehabilitacyjna, Warszawa.

Malik T. (2011). Szanse i bariery w edukacji i aktywizacji zawodowej osób niepełnosprawnych intelektualnie, [w:] Franczak M. (red.), Edukacja i aktywizacja zawodowa osób z niepełnosprawnościami, Wydawnictwo Państwowej Wyższej Szkoły Zawodowej im. Angelusa Silesiusa, Wałbrzych. 
Matson L.J., Benavidez D.A., Compton L.S., Paclawskyj T., Baglio C. (1996), Behavioral treatment of autistic person: A review of research from 1980 to the present. Research in Developmental Disabilities, 17.

Meder J. (1998). Osoby z zaburzeniami psychicznymi, [w:] Szczepankowska B., Ostrowska A. (red.), Problem niepełnosprawności w poradnictwie zawodowym. Zeszyty Informacyjno-Metodyczne Doradcy Zawodowego, Warszawa.

Mesibow G.B., Handlan S., (1997), Adolescents and adults with autism In Cohen D.J., Volkmar F.R. (Eds.), Handbook of Autism and Pervasive Developmental Disorders, New York.

Migas A. (2007). Możliwości zawodowe osób niepełnosprawnych ruchowo, „Praca i Rehabilitacja Niepełnosprawnych", nr 11-12.

Moskalewicz B. (1998), Osoby z niepełnosprawnością narządu ruchu z powodu chorób reumatycznych oraz amputacji kończyn, [w:] Ostrowska A., Szczepankowska B. (red.), Problem niepełnosprawności w poradnictwie zawodowym, Zeszyty Informacyjno-Metodyczne Doradcy Zawodowego, Krajowy Urząd Pracy, nr 10.

Mrugalska K. (1998), Osoby z upośledzeniem umysłowym, [w:] Szczepankowska B., Ostrowska A. (red.), Problem niepełnosprawności w poradnictwie zawodowym, Zeszyty Informacyjno-Metodyczne Doradcy Zawodowego, Warszawa.

Mrugalska K. (1996). Orientacja zawodowa oraz poradnictwo i szkolenie zawodowe osób z upośledzeniem umysłowym, „Problemy Rehabilitacji Społecznej i Zawodowej”, nr 4.

Noskowicz-Bieroniowa H. (2000), Zmagania z padaczką, Agencja Wydawniczo-Usługowa Emilia, Kraków.

Oleś M. (1998), Asertywność u dzieci w okresie wczesnej adolescencji, Towarzystwo Naukowe KUL, Lublin.

Polak-Sopińska A. (2008), Przystosowanie stanowisk pracy do indywidualnych możliwości osób niepełnosprawnych, podstawą ich aktywizacji zawodowej, [w:] Barczyński A. (red.), Społeczne korzyści zatrudniania osób niepełnosprawnych, nr 54, KIG-R, Warszawa.

Rozporządzenie Ministra, Gospodarki, Pracy i Polityki społecznej z dnia 15 lipca 2003 r., w sprawie orzekania o niepełnosprawności i stopniu niepełnosprawności (Dz. U. nr 139, poz. 1328, z późn. zm).

Suchińska A. (2008), Gdzie i jak pracują osoby badane? In Łukowski W. Osoby z ograniczoną sprawnością na rynku pracy - portret środowiskowy, Wydawnictwo Warszawa Szkoły Wyższej Psychologii Społecznej,,Academica”.

Safilios-Rothschild C. (1976), The socjology and Psychology of Disability and Rehabilitation. For Sokołowska M., Ostrowska A. Socjologia kalectwa i rehabilitacji. Wybrane problemy, PAN, IFiS, Warszawa.

Stan zdrowia ludności (2004), https://stat.gov.pl/obszary-tematyczne/zdrowie/zdrowie/stan-zdrowia-ludnosci-polski-2004-r,6,4.html [access: 31.01.2019]. 
Szczepankowski B. (1998). Osoby z uszkodzonym słuchem, [w:] Szczepankowska B., Ostrowska A. (red.), Zeszyt informacyjno-metodyczny, nr 10, Warszawa.

Szczupał B. (2007). Wybrane problemy zatrudnienia osób z autyzmem, „Aktywizacja Zawodowa Osób Niepełnosprawnych" nr 1.

Teczka informacyjna. Sprawni niepełnosprawni (2005), Centrum Informacji i Planowania Kariery Zawodowej. Wojewódzki Urząd Pracy w Warszawie, Warszawa - Ciechanów.

Tokarski T., Myrcha K., Kamińska J., Konarska M., Kurkus-Rozowska B., Łuczak A., Serafin R. (2007), Materiały szkoleniowe dla służb BHP tworzonych w spółdzielniach ze szczególnym uwzględnieniem stanowiska pracy, COP, PIB, Warszawa.

Tylka J. (1998), Osoby z chorobami układu krążenia - niektóre aspekty, [w:] Szczepankowska B., Ostrowska A. (red.), Problem niepełnosprawności w poradnictwie zawodowym. Zeszyty Informacyjno-Metodyczne Doradcy Zawodowego, Krajowy Urząd Pracy, Warszawa.

Walkowska W. (2008). Bariery w readaptacji osób niesłyszących, [w:] Frąckiewicz L. Przeciw wykluczeniu społecznemu osób niepełnosprawnych, Warszawa.

Wiliams D. (2005), Nikt nigdzie. Wydawnictwo Fraszka Edukacyjne we współpracy z Fundacja SYNAPSIS. Warszawa. 